\title{
Bowel Necrosis Induced by Tumor Necrosis Factor in Rats Is Mediated by Platelet-activating Factor
}

\author{
Xiao-ming Sun and Wei Hsueh \\ Department of Pathology, Children's Memorial Hospital, Northwestern University, Chicago, Illinois 60614
}

\begin{abstract}
We have developed a rat model of ischemic bowel necrosis associated with shock by injection of platelet-activating factor (PAF) or a combination of PAF and endotoxin. Recent investigations have shown that tumor necrosis factor (TNF) also induces shock and necrosis of the gastrointestinal tract. The morphological changes of TNF-induced bowel lesions are indistinguishable from those caused by PAF. The mechanism of TNF-induced bowel necrosis is unclear. In the present study, we have shown that (a) TNF caused PAF production in bowel tissue; (b) the effects of TNF and LPS on PAF production in the intestine are additive; (c) TNF and LPS are synergistic in inducing bowel necrosis; and (d) TNF-induced bowel necrosis is due to PAF release and can be prevented by pretreatment with PAF antagonists.
\end{abstract}

\section{Introduction}

Tumor necrosis factor (TNF- $\alpha)^{1}$ (1) or cachectin (2), a product of macrophages activated by BCG and LPS $(1,2)$, is being increasingly recognized as an important monokine that plays a major role in the inflammatory response $(3,4)$. Besides causing necrosis of tumor cells (1) and cachexia (2), recent investigations have shown that TNF can induce shock, tissue injury, and necrosis of the gastrointestinal tract (5). It has been reported that TNF caused release of other mediators such as IL 1 $(6,7)$, PGs $(4,7)$, and collagenase (4), and that the actions and interactions of these cytokines and mediators may account for the pathophysiological changes in endotoxin shock. Although it is well-known that ischemic bowel necrosis is often associated with shock or sepsis, the role of TNF in causing bowel necrosis is unclear. We have developed a rat model of ischemic bowel necrosis by injection of platelet-activating factor (PAF) or a combination of PAF and LPS (8), in which the lesions are morphologically indistinguishable from those induced by TNF (5). It is possible that PAF is a secondary mediator of TNF or vice versa. In the present study we have provided evidence to suggest that TNF-induced bowel necrosis is due to PAF release. We have also shown that the effects of TNF and LPS on

Address reprint requests to Dr. Wei Hsueh, Department of Pathology, Children's Memorial Hospital, 2300 Children's Plaza, Chicago, IL 60614.

Received for publication 31 July 1987 and in revised form $18 \mathrm{No}$ vember 1987.

1. Abbreviations used in this paper: Hct, hematocrit; PAF, platelet-activating factor; TNF, tumor necrosis factor.

J. Clin. Invest.

(C) The American Society for Clinical Investigation, Inc. 0021-9738/88/05/1328/04 \$2.00

Volume 81, May 1988, 1328-1331
PAF production in the intestine are additive, and LPS and TNF are synergistic in inducing bowel necrosis.

\section{Methods}

Young male Sprague-Dawley rats with body weights of $60-80 \mathrm{~g}$ were used in all experiments. The carotid artery was catheterized for continuous recording of blood pressure, and the jugular vein was cannulated for injections of $0.5 \mathrm{mg} / \mathrm{ml}$ recombinant TNF- $\alpha$ (Genentech, Inc., South San Francisco, CA) and/or bacterial endotoxin (LPS, Salmonella typhosa; Difco, Detroit, MI) and withdrawing blood samples for white blood cell count and hematocrit $(\mathrm{Hct})$ determination. The animals were divided into six groups: (a) control, (i.e., sham operated), (b) $0.5 \mathrm{mg} / \mathrm{kg} \mathrm{TNF},(c) 1 \mathrm{mg} / \mathrm{kg} \mathrm{TNF}$, (d) $200 \mu \mathrm{g} / \mathrm{kg} \mathrm{LPS,} \mathrm{(e)} 0.5 \mathrm{mg} / \mathrm{kg}$ TNF followed $1 \mathrm{~h}$ later by $200 \mu \mathrm{g} / \mathrm{kg} \mathrm{LPS}$, and $(f)$ the same as $e$, except for pretreatment with $5 \mathrm{mg} / \mathrm{kg} \mathrm{SRI} \mathrm{63-119} \mathrm{(divided} \mathrm{into} \mathrm{two} \mathrm{doses,}$ injected $20 \mathrm{~min}$ before TNF and $10 \mathrm{~min}$ before LPS). All chemicals were slowly injected into the jugular vein.

At the end of the experiment ( $3 \mathrm{~h}$ after the first injection), the small intestine was removed and examined. The length that appeared necrotic was recorded and expressed as a percentage of the total length. Representative sections were taken and fixed in $10 \%$ formalin, and were later processed for histological examination as previously described (8). The remaining small bowel was washed with saline, minced, homogenized in methanol, and stored at $-70^{\circ} \mathrm{C}$ for later PAF extraction.

Extraction and bioassay of PAF in the intestinal tissue were performed as previously reported (9). Briefly, $10^{6} \mathrm{cpm}$ of $\left[{ }^{3} \mathrm{H}\right] \mathrm{PAF}$ (Amersham Corp., Arlington Heights, IL) was added to the sample for calculation of extraction efficiency, and the total lipid was extracted by Bligh and Dyer's method (10). The extracted lipid was plated on a thin layer plate coated with silica gel $\mathbf{G}$, and developed in solvent system chloroform/methanol/water, 65:35:6 (vol/vol/vol). The zone comigrated with standard PAF was scraped, repeatedly eluted with chloroform/methanol/water, 1:2:0.8 (vol/vol/vol) (9), and dried. An aliquot was counted for estimation of recovery, and another aliquot was reconstituted in PBS containing $5 \mathrm{mg} / \mathrm{ml}$ BSA, and assayed for PAF activity. PAF was assayed by platelet serotonin release as previously described (9). $10 \mu \mathrm{g} / \mathrm{ml} \mathrm{SRI} \mathrm{63-119} \mathrm{was} \mathrm{used} \mathrm{in} \mathrm{the} \mathrm{assay} \mathrm{to} \mathrm{confirm}$ that the active compound in the solution was PAF (9).

\section{Results and Discussion}

As shown in Table I, $200 \mu \mathrm{g} / \mathrm{kg}$ LPS or a low dose $(0.5 \mathrm{mg} / \mathrm{kg})$ of TNF alone did not cause any gross or microscopic bowel lesions. In contrast, all five animals treated with the combination of TNF and LPS developed focal bowel necrosis. The involvement varied from 10 to $60 \%$ of the small bowel, and microscopically, from mild to moderate degrees of necrosis (Table I). Analysis of the PAF content in the small intestine showed that although both TNF $(0.5 \mathrm{mg} / \mathrm{kg})$ and LPS induced PAF production in the intestinal tissue $(0.86 \pm 0.31 \mathrm{ng} / \mathrm{g}$ tissue and $1.28 \pm 0.45 \mathrm{ng} / \mathrm{g}$, respectively), the effect of TNF and LPS was additive: animals treated with the combination of TNF and LPS produced $2.08 \pm 0.44 \mathrm{ng} / \mathrm{g}$ of PAF, significantly different from the group receiving $0.5 \mathrm{mg} / \mathrm{kg}$ TNF alone $(P$ 
Table I. Effects of LPS, TNF, and PAF on Development of Bowel Necrosis, and the Prevention by PAF Antagonist

\begin{tabular}{|c|c|c|c|}
\hline Treatment & $\begin{array}{l}\text { No. of } \\
\text { animals }\end{array}$ & Gross lesions* & Microscopic necrosis ${ }^{\ddagger}$ \\
\hline None & 5 & 0 & 0 \\
\hline TNF $(0.5 \mathrm{mg} / \mathrm{kg})$ & 6 & 0 & 0 \\
\hline TNF $(1 \mathrm{mg} / \mathrm{kg})$ & 3 & $17 \pm 8 \%$ & Mild (2), moderate (1) \\
\hline TNF $(2 \mathrm{mg} / \mathrm{kg})$ & 3 & $18 \pm 5 \% * *$ & Mild (3) \\
\hline LPS $(200 \mu \mathrm{g} / \mathrm{kg})$ & 7 & 0 & 0 \\
\hline $\mathrm{TNF}(0.5 \mathrm{mg} / \mathrm{kg})+\mathrm{LPS}(200 \mu \mathrm{g} / \mathrm{kg})^{8}$ & 5 & $35 \pm 7 \%$ & Mild (1), moderate (4) \\
\hline SRI 63-1 $19^{\prime \prime}(5 \mathrm{mg} / \mathrm{kg})+$ TNF $(0.5 \mathrm{mg} / \mathrm{kg})+\mathrm{LPS}(200 \mu \mathrm{g} / \mathrm{kg})$ & 3 & 0 & 0 \\
\hline SRI $63-119+$ TNF $(1 \mathrm{mg} / \mathrm{kg})$ & 3 & 0 & 0 \\
\hline PAF $(1 \mu \mathrm{g} / \mathrm{kg})$ & 3 & 0 & 0 \\
\hline $\operatorname{TNF}(0.2 \mathrm{mg} / \mathrm{kg})+$ PAF $(1 \mu \mathrm{g} / \mathrm{kg})$ & 4 & $35 \pm 4 \%$ & Mild (1), moderate (3) \\
\hline
\end{tabular}

\begin{abstract}
* Gross lesions (violaceous, dark, and lusterless areas). ${ }^{\ddagger}$ Microscopic lesions are graded as previously reported (8). Mild: necrosis is confined to the tips of mucosal villi. Moderate: partial or total loss of villi, but necrosis is confined to the mucosal layer. Since the microscopic involvement was not uniform, pathology of the most severely involved areas are presented in the table. ${ }^{8} \mathrm{TNF}\left(5.02 \times 10^{7} \mathrm{U} / \mathrm{mg}, 0.5 \mathrm{mg} / \mathrm{kg}\right) \mathrm{was}$ injected intravenously $1 \mathrm{~h}$ before the intravenous injection of LPS. " $2.5 \mathrm{mg} / \mathrm{kg}$ of SRI 63-119 was injected intravenously 20 min before the TNF injection; another $2.5-\mathrm{mg} / \mathrm{kg}$ dose was injected $10 \mathrm{~min}$ before the LPS injection. ${ }^{* *}$ All three animals died within $2 \mathrm{~h}$. (One died within an hour.) Extent of gross lesions was less severe than in animals receiving $1 \mathrm{mg} / \mathrm{kg} \mathrm{TNF}$, probably because the shorter survival interval did not allow development of advanced lesions.
\end{abstract}

$<0.05$ ). Interestingly, control (sham operated) rats also contained small amounts of PAF in the intestinal tissue $(0.08 \pm 0.07 \mathrm{ng} / \mathrm{g})$. (Fig. 1).

The effects of TNF seemed to be dose related. However, due to the close proximity of the effective dose $(1 \mathrm{mg} / \mathrm{kg})$ and the lethal dose $(2 \mathrm{mg} / \mathrm{kg})$, a definite dose dependency could not be demonstrated. At the high dose $(1 \mathrm{mg} / \mathrm{kg})$, TNF induced gross and microscopic necrosis of the small bowel (Table I) and caused a marked increase in PAF production by the intestinal tissue $(2.03 \pm 0.25 \mathrm{ng} / \mathrm{g}$, Fig. 1). This increase is significantly higher than the group receiving the low dose $(0.5 \mathrm{mg} / \mathrm{kg})$ of TNF.

Other systemic changes were also observed in animals treated with a combination of $0.5 \mathrm{mg} / \mathrm{kg}$ TNF and $200 \mu \mathrm{g} / \mathrm{kg}$ LPS (Fig. 2). These rats developed profound hypotension and leukopenia, both of which are known systemic effects of PAF $(11,12)$. In contrast, the animals treated with LPS or a low dose $(0.5 \mathrm{mg} / \mathrm{kg})$ of TNF alone showed a minimal decrease in systemic BP, not significantly different from that of the shamoperated group. However, TNF alone, at a high dose (1 $\mathrm{mg} / \mathrm{kg}$ ), was effective in inducing mild hypotension and marked leukopenia (Fig. 2). Animals receiving LPS or lowdose TNF alone showed only mild leukopenia at the end of the experimental period. It is not known whether the drop in white blood cell count in these groups was due to PAF release. How-

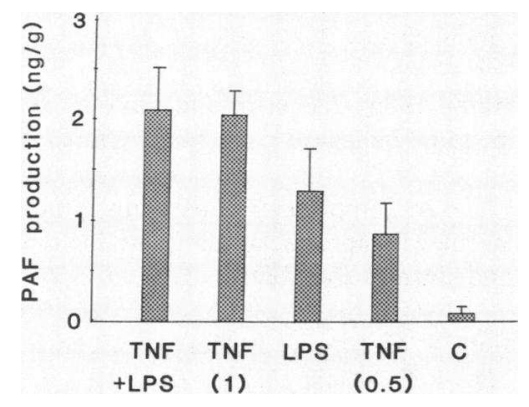

Figure 1. Production of PAF by the small intestine. Abbreviations: $\mathrm{C}$, control (sham operated); TNF (0.5), 0.5 $\mathrm{mg} / \mathrm{kg}$ TNF; TNF (1), 1 $\mathrm{mg} / \mathrm{kg}$ TNF; TNF + LPS: $0.5 \mathrm{mg} / \mathrm{kg}$ TNF $+200 \mu \mathrm{g} / \mathrm{kg}$ LPS. (mean \pm SEM.) ever, LPS or TNF by itself can directly activate PMNs and promote adhesion between PMNs and endothelial cells (13, 14), thus enhancing the leukopenic effect of PAF. None of the five groups showed any changes in Hct. Although hemoconcentration is also a well-known systemic effect of PAF, the dose required for Hct changes largely exceeds the amount that was endogenously generated in our experiments (12).

The bowel necrosis induced by injection of the combination of $0.5 \mathrm{mg} / \mathrm{kg}$ TNF and LPS could be completely prevented by pretreatment with a PAF antagonist, SRI 63-1 19 (a generous gift from Sandoz Research Institute, East Hanover, NJ) (15) (5 mg/kg) (Table I). Other systemic changes, e.g., hypotension and leukopenia, were also significantly ameliorated (Fig. 2). Pretreatment of the animal with SRI 63-119 also abolished the development of intestinal necrosis caused by the high dose of TNF $(1 \mathrm{mg} / \mathrm{kg})$ and ameliorated the hypotensive and leukopenic effects of TNF (data not shown).

PAF is an endogenous mediator (16-18) that causes profound shock $(11,12)$ and ischemic bowel necrosis $(8)$ in animals. It has been shown to be released in endotoxemia (18). Ischemic bowel necrosis is often associated with shock or infection; thus, it is possible that PAF is a mediator for the development of bowel necrosis. In our previous investigations, we have shown that $7 \mu \mathrm{g} / \mathrm{kg}$ PAF (8) or a high dose of LPS alone (>10 mg/kg) (unpublished observation) could cause ischemic bowel necrosis, and that the effects of LPS and PAF are synergistic (8): $80 \mu \mathrm{g} / \mathrm{kg}$ LPS in combination with 0.35 $\mu \mathrm{g} / \mathrm{kg}$ PAF could induce necrotic lesions in the bowel. These observations suggest that PAF, which is released in endotoxemia (18), acts synergistically with LPS to induce bowel necrosis during shock or sepsis. Our present study further demonstrates that TNF, another proposed mediator of shock (5, 19), which has also been reported to produce bowel necrosis (5), acts synergistically with LPS in causing necrotic lesions in the bowel. TNF and LPS also acted additively to induce local formation of PAF. Furthermore, the mechanism of action of TNF was probably via release of PAF, since pretreatment with 


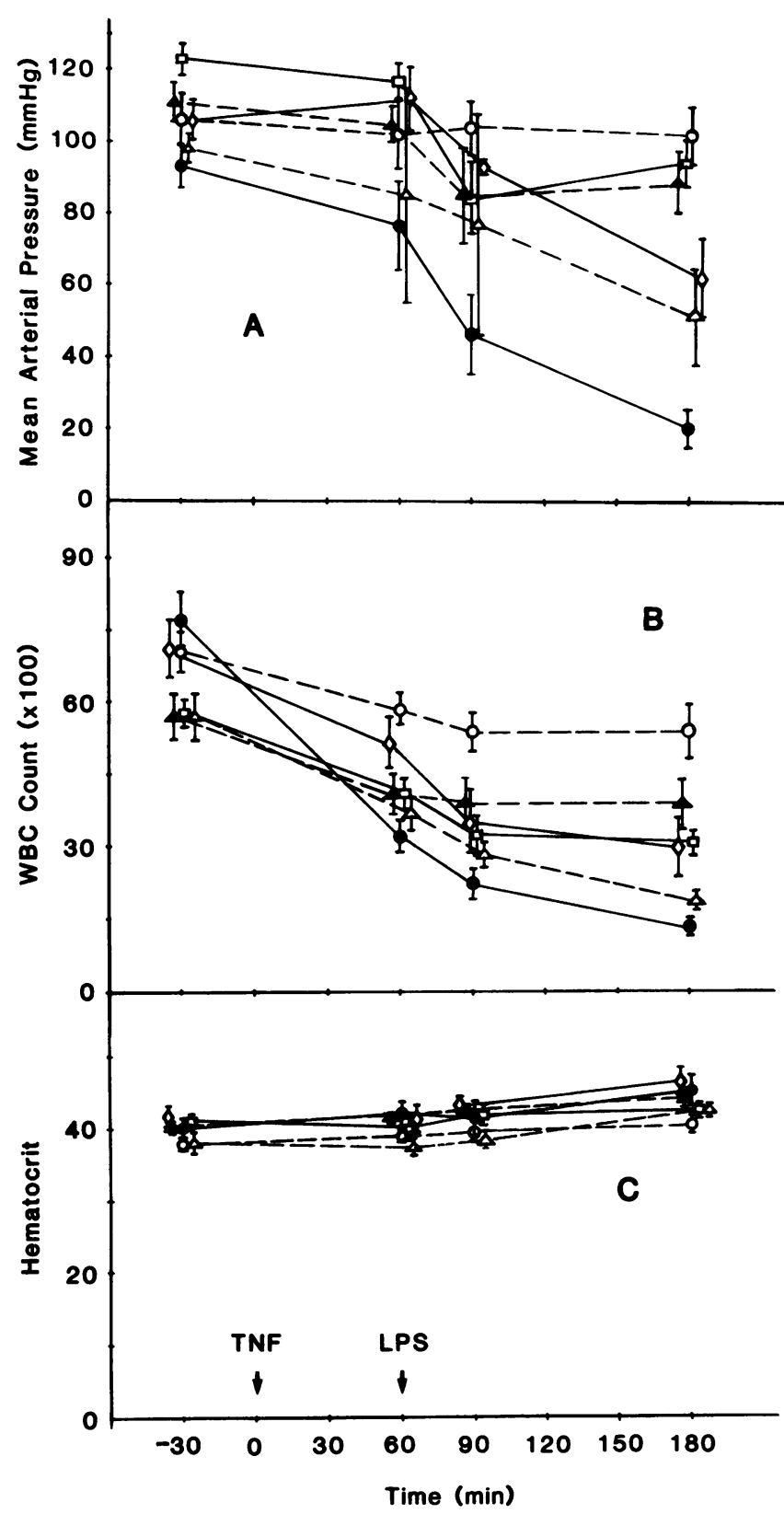

Figure 2. Effects of TNF and LPS on $(A)$ mean arterial pressure, $(B)$ WBC count, $(C)$ Hct, and prevention by SRI 63-119. o, control, i.e., sham operated; $\Delta, 0.5 \mathrm{mg} / \mathrm{kg}$ TNF injected at time $0 ; \Delta, 1 \mathrm{mg} / \mathrm{kg}$ TNF injected at time $0 ; \square, 200 \mu \mathrm{g} / \mathrm{kg}$ LPS injected at time $0 ; \bullet, 0.5$ $\mathrm{mg} / \mathrm{kg}$ TNF injected at time $0+$ LPS injected at $60 \mathrm{~min}$; and $\diamond, 5$ $\mathrm{mg} / \mathrm{kg}$ SRI 63-119 divided into two doses, injected $20 \mathrm{~min}$ before TNF and $10 \mathrm{~min}$ before LPS $+0.5 \mathrm{mg} / \mathrm{kg}$ TNF, injected at time 0 + LPS injected at $60 \mathrm{~min}$.

the PAF antagonist totally prevented bowel necrosis caused by TNF and LPS.

It remains to be demonstrated whether TNF, without interaction with LPS, can produce shock and bowel necrosis. It is not clear if the TNF preparation used by Tracey et al. (5) was uncontaminated by LPS. Although the TNF preparation in the present study is relatively free of LPS (LPS $<0.125$ $\mathrm{EU} / \mathrm{ml}$ ), and we have observed that injection of high doses of TNF alone resulted in hypotension and intestinal necrosis, these responses were slow; there was sufficient time for absorption of LPS from the intestine (after an initial minor mucosal injury), which may have acted synergistically with TNF.

It is interesting to note that such a small amount of PAF produced in vivo (see Table I) was sufficient to cause necrotic lesions in the bowel, whereas a relatively large amount of exogenous PAF was needed to produce similar lesions in our previous experiments (8). This is probably, at least in part, due to a synergism of TNF and PAF. We have observed gross necrotic lesions in the bowel (confirmed by microscopic examination) in all four rats treated with $0.2 \mathrm{mg} / \mathrm{kg}$ of TNF and $1 \mu \mathrm{g} / \mathrm{kg}$ of PAF (Table I). This dose of PAF is less than one-fifth of what was needed to produce bowel necrosis, if administered exogenously.

There seems to be a great variation in the levels of endogenous TNF production and responses to exogenous TNF administration among different species. In humans, the level of endogenous TNF production is very low $(<30 \mathrm{ng} / \mathrm{ml})(19)$; the doses used $\left(\leq 200 \mu \mathrm{g} / \mathrm{m}^{2}\right)(20)$ in clinical trials were much lower than those used in our experiments. In this study a bolus dose of TNF was used. Considering the continuous production and the rapid degradation of TNF in vivo (21), the dose used could be comparable to what was detected in vivo in rodents (22) and rabbits (23). Thus, the present study seems relevant to the pathophysiology of endotoxin shock and ischemic bowel necrosis. It has been suggested that TNF is an initiating factor of shock elicited by LPS $(24,25)$. Because of its activating effects on inflammatory cells (14) and endothelial cells (26), and its action in releasing other mediators such as IL $1(6,7)$, PGs $(4,7)$, and collagenase (4), TNF is considered a major cytokine that may initiate a cascade of inflammatory and coagulative events in the pathogenesis of septic shock and tissue injury. Since LPS administration causes production of TNF (21) and PAF (18), the synergistic effects between LPS and PAF, and between TNF and LPS, may play an important role in the development of irreversible shock and bowel necrosis.

\section{Acknowledgments}

We are grateful to Dr. H. M. Shepard at Genentech, Inc. for providing us with the recombinant human tumor necrosis factor-alpha, and to Dr. R. Saunders at Sandoz Research Institute for giving us SRI 63-119.

This work is partly supported by National Institutes of Health grant DK-34574.

\section{References}

1. Carswell, E. A., L. J. Old, R. L. Kassel, S. Green, N. Fiore, and B. Williamson. 1975. An endotoxin-induced serum factor that causes necrosis of tumors. Proc. Natl. Acad. Sci. USA. 72:3666-3670.

2. Beutler, B., J. Mahoney, N. Le Trang, P. Pekala, and A. Cerami. 1985. Purification of cachectin, a lipoprotein lipase-suppressing hormone secreted by endotoxin-induced raw 264.7 cells. J. Exp. Med. 161:984-995.

3. Beulter, B., and A. Cerami. 1986. Cachectin and tumour necrosis factor as two sides of the same biological coin. Nature (Lond.). 320:584-588.

4. Dayer, J.-M., B. Beutler, and A. Cerami. 1985. Cachectin/tumor necrosis factor stimulates collagenase and prostaglandin $\mathrm{E}_{2}$ production by human synovial cells and dermal fibroblasts. J. Exp. Med. 162:2163-2168.

5. Tracey, K. J., B. Beutler, S. F. Lowry, J. Merryweather, S. Wolpe, I. W. Milsark, R. J. Hariri, T. J. Fahey III, A. Zentella, J. D. 
Albert, G. T. Shires, and A. Cerami. 1986. Shock and tissue injury induced by recombinant human cachectin. Science (Wash. DC). 234:470-474.

6. Nawroth, P. P., I. Bank, D. Handley, J. Cassimeris, L. Chess, and D. Stern. 1986. Tumor necrosis factor/cachectin interacts with endothelial cell receptors to induce release of interleukin 1. J. Exp. Med. 163:1363-1375.

7. Bachwich, P. R., S. W. Chensue, J. W. Larrick, and S. L. Kunkel. 1986. Tumor necrosis factor stimulates interleukin 1 and prostaglandin $\mathrm{E}_{2}$ production in resting macrophages. Biochem. Biophys. Res. Commun. 136:94-101.

8. Gonzalez-Crussi, F., and W. Hsueh. 1983. Experimental model of ischemic bowel necrosis: the role of platelet-activating factor and endotoxin. Am. J. Pathol. 112:127-135.

9. Hsueh, W., F. Gonzalez-Crussi, and J. L. Arroyave. 1987. Platelet activating factor is an endogenous mediator for bowel necrosis in endotoxemia. FASEB (Fed. Am. Soc. Exp. Biol.) J. 1:403-405.

10. Bligh, E. G., and W. J. Dyer. 1959. A rapid method of total lipid extraction and purification. Can. J. Biochem. Physiol. 37:911-917.

11. Halonen, M., J. D. Palmer, I. C. Lohman, L. M. McManus, and R. N. Pinckard. 1980. Respiratory and circulatory alterations induced by acetyl glyceryl ether phosphorycholine, a mediator of IgE anaphylaxis in the rabbit. Am. Rev. Respir. Dis. 122:915-924.

12. Sánchez-Crespo, M., F. Alonso, P. Iñarrea, V. Alvarez, and J. Egido. 1982. Vascular actions of synthetic PAF-acether (a synthetic platelet-activating factor) in the rat: evidence for a platelet independent mechanism. Immunopharmacology. 4:173-185.

13. Morrison, D. C., and R. J. Ulevitch. 1978. The effects of bacterial endotoxin on host mediation. Am. J. Pathol. 93:527-617.

14. Klebanoff, S. J., M. A. Vadas, J. M. Harlan, L. H. Sparks, J. R. Gamble, J. M. Agosti, and A. M. Waltersdorph. 1986. Stimulation of neutrophils by tumor necrosis factor. J. Immunol. 136:4220-4225.

15. Hsueh, W., F. Gonzalez-Crussi, J. L. Arroyave, R. C. Anderson, M. L. Lee, and W. J. Houlihan. 1986. Platelet activating factorinduced ischemic bowel necrosis: the effect of PAF antagonists. Eur. J. Pharmacol. 123:79-83.
16. Vargaftig, B. B., M. Chignard, J. Benveniste, J. Lefort, and F. Wal. 1981. Background and present status of research on platelet-activating factor (PAF-acether). Ann. NY Acad. Sci. 370:1 19-137.

17. Henson, P. M., and J. M. Lynch. 1983. Cellular origins of PAF. In Platelets-Activating Factor and Structurally Related Ether Lipids. J. Benveniste and B. Arnoux, editors. Elsevier Science Publishing Co. Inc., New York. 75-82.

18. Chang, S. W., C. O. Feddersen, P. M. Henson, and N. F. Voelkel. 1987. Platelet-activating factor mediates hemodynamic changes and lung injury in endotoxin-treated rats. J. Clin. Invest. 79:1498-1509.

19. Waage, A., A. Halstensen, and T. Espevik. 1987. Association between tumour necrosis factor in serum and fatal outcome in patients with meningococcal disease. Lancet i:355-357.

20. Blick, M., S. A. Sherwin, M. Rosenblum, and J. Gutterman. 1987. Phase I study of recombinant tumor necrosis factor in cancer patients. Cancer Res. 47:2986-2989.

21. Beutler, B. A., I. W. Milsark, and A. Cerami. 1985. Cachetin/ tumor necrosis factor: production, distribution and metabolic fate in vivo. J. Immunol. 135:3972-3977.

22. Haranaka, K., E. A. Carswell, B. D. Willamson, J. S. Prendergast, N. Satomi, and L. J. Old. 1986. Purification, characterization, and antitumor activity of nonrecombinant mouse tumor necrosis factor. Proc. Natl. Acad. Sci. USA. 83:3949-3953.

23. Abe, S., T. Gatanaga, M. Yamazaki, G. Soma, and D. Mizuno. 1985. Purification of rabbit tumor necrosis factor. FEBS (Fed. Eur. Biochem. Soc.) Lett. 180:203-206.

24. Bauss, F., W. Dröge, and D. N. Mannel. 1987. Tumor necrosis factor mediates endotoxic effects in mice. Infect. Immun. 55:16221625.

25. Beutler, B., I. W. Milsark, and A. Cerami. 1985. Passive immunization against cachectin/tumor necrosis factor protects mice from lethal effects of endotoxin. Science (Wash. DC). 229:869-871.

26. Nawroth, P. P., and D. M. Stem. 1986. Modulation of endothelial cell hemostatic properties by tumor necrosis factor. J. Exp. Med. 163:740-745. 